\title{
WORK FAMILY CONFLICT, STRES KERJA, KEPUASAN KERJA BEPENGARUH TERHADAP KOMITMEN ORGANISASIONAL PEGAWAI
}

\author{
Ni Nyoman Ayu Manik Ankgaryta Pramana ${ }^{1}$ \\ Ni Wayan Mujiati ${ }^{2}$ \\ Fakultas Ekonomi dan Bisnis Universitas Udayana (Unud), Bali, Indonesia \\ email: ayuupramanaa@gmail.com
}

\begin{abstract}
ABSTRAK
Komitmen organisasional merupakan suatu kekuatan yang mengikat perorangan kepada suatu tindakan keterkaitan pada target. Ketika pegawai berkomitmen terhadap organisasi mereka akan loyal terhadap organisasi dan memberikan yang tebaik untuk organisasi. Tujuan penelitian ini untuk mengetahui pengaruh work family conflict, stres kerja, dan kepuasan kerja terhadap komitmen organisasional pegawai Bank BRI Unit Diponogoro Denpasar dengan sampel sebanyak 45 orang, menggunakan metode sampel jenuh. Pengumpulan data melalui wawancara dan kuesioner, dianalisis dengan Regresi Linier Berganda. Hasil menunjukkan work family conflict dan stres kerja berpengaruh negatif dan signifikan terhadap komitmen organisasional, sedangkan kepuasan kerja yang berpengaruh positif dan signifikan terhadap komitmen organisasional. Penelitian ini memberikan pemahaman bahwa Work Family Conflict, Stres Kerja menurunkan Komitmen Organisasional pegawai dan Kepuasan Kerja secara nyata dapat meningkatkan Komitmen Organisasional pegawai.

Kata kunci : Work Family conflict, Stres Kerja, Kepuasan Kerja, Komitmen Organisasional.
\end{abstract}

\begin{abstract}
Organizational commitment is a force that binds individuals to an action related to the target. When employees are committed to the organization they will be loyal to the organization and provide the best for the organization. The purpose of this study was to determine the effect of work family conflict, job stress, and job satisfaction on organizational commitment of Bank BRI Diponogoro Denpasar Unit employees with a sample of 45 people, using the saturated sample method. Data collection through interviews and questionnaires, analyzed by Multiple Linear Regression. The results show that work family conflict and work stress have a negative and significant effect on organizational commitment, while job satisfaction has a positive and significant effect on organizational commitment. This study provides an understanding that Work Family Conflict, Job Stress decreases employee Organizational Commitment and Job Satisfaction can significantly increase employee Organizational Commitment.

Keywords: Work Family conflict, Job Stress, Job Satisfaction, Organizational Commitment
\end{abstract}




\section{PENDAHULUAN}

Perusahaan merupakan suatu organisasi yang terdiri atas sekelompok orang yang bekerja untuk mencapai suatu tujuan. Kepentingan yang paling mendasar yaitu mendapatkan keuntungan atau laba semaksimal mungkin serta kesejahteraan bagi para pemegang saham perusahaan. Sumber Daya Manusia di dalam sebuah perusahaan merupakan salah satu aset terpenting. Manusia memiliki kemampuan yang berbeda dengan sumber daya lainnya dimana manusialah yang dapat menggerakkan sumberdaya lain di dalam organisasi (Arifin, 2015). Selain menangani masalah ketrampilan dan keahlian, sumber daya manusia juga berkewajiban membangun perilaku kondusif untuk mendapatkan kinerja terbaik. Oleh karena itu perusahaan selalu berusaha agar sumber daya manusia yang dimilikinya memberikan kontribusi yang maksimal serta memiliki komitmen terhadap perusahaan agar mencapai tujuan yang diharapkan (Wang et al., 2017).

Komitmen organisasi diperlukan sebagai salah satu indikator kinerja pegawai. Komitmen organisasional merupakan suatu kekuatan yang mengikat perorangan kepada suatu tindakan keterkaitan pada satu atau lebih target (Sunarno \& Liana, 2015). Pegawai dengan komitmen yang tinggi dapat diharapkan akan memperlihatkan kinerja optimal. Komitmen organisasi adalah derajat yang mana pegawai percaya dan menerima tujuan-tujuan organisasi. Komitmen organisasional sangat diperlukan untuk kesuksesan organisasi, ketika pegawai berkomitmen terhadap organisasi mereka akan loyal terhadap organisasi dan memberikan yang tebaik untuk organisasi (Batur \& Nart, 2015). Komitmen organisasional yang di miliki oleh anggota akan memiliki dampak yang baik terhadap organisasi tempatnya bekerja, serta lebih termotivasi dalam bekerja. Komitmen organisasional dikonsepkan sebagai hubungan pegawai dengan organisasi tempat ia bekerja dalam berbagai nilai-nilai organisasi, yang menunjukkan keinginan mereka untuk bertahan dalam organisasi tersebut (Harun et al., 2015)

Ketika ketiga komponen untuk terwujudnya komitmen pegawai tidak terpenuhi dengan baik maka seringkali berdampak buruk terhadap perusahaan. Faktor yang dapat menentukan anggota memiliki komitmen organisasional pada organisasinya dapat dipengaruhi oleh work family conflict (Yantha, 2015) . Work family conflict adalah sebagai bentuk konflik dimana, tekanan peran ynag terkait dengan keanggotaan dalam suatu organisasi yang bertentangan dengan tekanan yang berasal dari keanggotaan keluarga (Malik et al., 2015)

Work family conflict sebagai bentuk gangguan dari lingkungan pekerjaan terhadap kehidupan pribadi pegawai, ketika individu memilih bekerja maka akan berpotensi mengalami kendala dalam memenuhi kewajiban dikeluarganya . Ketika pegawai lebih memperhatikan pekerjaanya dikantor dan mengurangi perhatian bersama keluarga karena pegawai merasa sangat rugi ketika meninggalkan perusahaan, hal tersebut menunjukan semakin tinggi tingkat tingkat konflik pekerjaan-keluarga maka cenderung mengurangi komitmen organisasi (Malik, 2015). Work family conflict dapat mempengaruhi stres kerja, work family conflict yang terjadi secara terus menerus akan memberikan tekanan-tekanan yang menimbulkan stres kerja akibat berkurangnya waktu yang dihabiskan bersama keluarga. Hasil penelitian dari Divara (2016) mengatakan bahwa work family 
conflict berpengaruh negatif signifikan terhadap komitmen organisasional. Semakin rendah konflik makan semakin tinggi komitmen terhadap perusahaan.

Ketidaknyamanan pegawai seringkali mengakibatkan rasa tertekan atau stres. Stres adalah respon fisik dan emosional yang terjadi saat kemampuan dan sumber daya pegawai tidak dapat diatasi dengan tuntutan dan kebutuhan dari pekerjaan mereka (Jamadin et al., 2015). Stres kerja akan timbul apabila beban kerja dan tugas-tugas yang diberikan harus diselesaikan segera yang menyebabkan rasa tertekan, yang dimana hal tersebut akan menurunkan komitmen pegawai terhadap perusahaan karena stres yang dialami oleh pegawai dapat mempengaruhi persepsi mereka terhadap keselarasan antara tujuan dan nilai individu dengan organisasi. Moura et al. (2015) gejala individu yang mengalami stres antara lain pekerjaan yang tidak terselesaikan, keterlambatan masuk kerja yang sering, ketidakhadiran pekerjaan, kesulitan membuat keputusan, kesalahan yang sembrono, kelalaian menyelesaikan pekerjaan, kesulitan berhubungan dengan orang lain, kerisauan tentang kesalahan yang dibuat. Efek berlebihan dari stres ini dapat menurunkan kinerja pegawai yang dimana berdampak negatif terhadap kepuasan kerja karywan.

Hasil penelitian dari Kusumandari et al. (2017) menyatakan bahwa Stres kerja berpengaruh negatif dan signifikan terhadap komitmen organisasional. Dalam penelitian Divara (2016) juga menyatakan bahwa stres kerja berpengaruh negatif signifikan terhadap komitmen organisasional. Komitmen organisasional akan akan tercipta apabila seorang dapat mengatasi tekanan atau stres dalam bekerja Iresa et al. (2015) menyatakan bahwa ada pengaruh signifikan stres kerja terhadap komitmen organisasional. Semakin tinggi tingkan stres kerja makan semakin rendah komitmen terhadap perusahaan yang dimana berdampak pada kepuasan kerja pegawai.

Kepuasan kerja pegawai adalah seperangkat perasaan pegawai tentang menyenangkan atau tidaknya pekerjaan mereka. Oleh karna itu kepuasan kerja di dalam suatu perusahaan sangatlah penting. Pada dasarnya kepuasan kerja pegawai memiliki tingkat kepuasan yang berbeda-beda karena suatu kepuasan bersifat individu dan sesuai dengan karakteristik yang berlaku pada dirinya (Nurcahyani \& Adnyani, 2016).. Jika pegawai merasa tidak puas akan pencapainnya makan akan menurunkan komitmennya terhadap perusahaan. Kepuasan kerja merupakan sesuatu bersifat individual dan setiap individu memiliki tingkat kepuasan berbeda sesuai sistem nilai yang berlaku pada dirinya (Malik, 2015).

Hasil peneltian dari Ariawan \& Sariyathi (2018) bahwa kepuasan kerja berpengaruh positif dan signifikan terhadap komitmen organisasi pegawai. Penelitan tersebut juga di dukung oleh penelitaian Utama et al. (2015) bahwa kepuasan kerja berpengaruh positif dan signifikan terhadap komitmen organisasional. Hal ini menunjukkan bahwa semakin tinggi kepuasan kerja maka akan semakin tinggi pula komitmen kerja pegawai. Berdasarkan pendapat tersebut menunjukkan bahwa work family conflict, stres kerja dan kepuasan kerja mampu mempengaruhi komiitmen organisasional.

Penelitian ini dilakukan di Bank BRI Unit Diponogoro Denpasar. Bank BRI merupakan salah satu Bank BUMN terbesar di Indonesia. Sebanyak 46 pegawai yang terdiri dari Kepala Unit, Supervisor, Mantri, Teller, Customer Service, PA 
KUR, Pramubakti, Satpam, Penjaga Malam, bidang-bidang ini memiliki tanggung jawab dan beban kerja yang bervariasi sehingga dibutuhkan SDM yang berkualitas dan berkomitmen terhadap organisasi dalam rangka mencapai tujuan organisasi. Banyaknya beban kerja dan tanggung jawab beban kerja keluarga yang tinggi akan membuat pegawai tidak berkomitmen terhadap organisasi.

Tabel 1.

Jumlah pegawai bank BRI Unit Diponogoro Denpasar berdasarkan jambatan dan masa kerja

\begin{tabular}{ccccc}
\hline No & Jabatan & Masa Kerja (Bulan) & Jumlah & Presentase(\%) \\
\hline 1 & Kepala Unit & 24 & 1 & 0,21 \\
2 & Supervisor & 19 & 1 & 0,21 \\
3 & Mantri & $12-24$ & 19 & 4,13 \\
4 & Taller & $15-19$ & 6 & 1,30 \\
5 & Pramubakti & $12-19$ & 3 & 0,65 \\
6 & Customer Service & $12-24$ & 7 & 1,52 \\
7 & PA KUR & $18-24$ & 2 & 0,43 \\
8 & Satpam & $12-18$ & 5 & 1,08 \\
9 & Penjaga Malam & $12-18$ & 2 & 0,43 \\
& Jumlah & - & 46 & 100 \\
\hline
\end{tabular}

Sumber : Bank BRI Unit Diponogoro Denpasa, 2019

Setiap orang yang bekerja dalam sebuah organisasi, harus memiliki komitmen dalam bekerja karena apabila pegawainya tidak memiliki komitmen terhadap organisasinya maka tujuan dari organisasi akan sulit tercapai. Perusahaan untuk mencapai tujuannya memerlukan pegawai yang memiliki komitmen yang tinggi terhadap organisasi. Berdasarkan hasil pra-riset dengan metode wawancara di BRI Unit Diponogoro Denpasar, terhadap 10 orang pegawai dengan masa kerja lebih dari 1 tahun

Tabel 1. menunjukkan bahwa rentan masa kerja tertinggi adalah posisi mantri dan customer service dengan masing-masing jumlah pegawai sebesar 19 orang dengan presentase 4,13 dan 7 orang dengan presentase 1,52. Sedangkan rentan masa kerja pegawai terendah adalah satpam dengan jumlah pegawai 5 orang dengan presentase 1,08 dan penjaga malam dengan jumlah pegawai 2 orang dengan presentase 0,43 persen. Pada tabel tersebut juga menjelaskan bahwa masa kerja pegawai Bank BRI di Unit hanya dikontrak 24 bulan. Setelah masa kontrak selama 24 bulan pegawai akan di pindahkan ke unit atau cabang lain, hal ini diberlakukan untuk menghindari terjadinya kecurangan antar pegawai. Akan tetapi jika rentan kontrak yang diberikan hanya 24 bulan pegawai akan sulit untuk berkomitmen terhadap perusahaan.

Hasil wawancara pra-riset mereka menyatakan komitmen organisasional yang dimiliki pegawai di BRI Unit Diponogoro Denpasar dikategorikan rendah. Kondisi ini dapat dilihat dari beberapa pegawai yang merasa beban kerja yang diberikan oleh organisasi sangat menyita waktu berkumpul bersama keluarga, sehingga dapat menimbulkan kurangnya keinginan pegawai untuk berkomitmen terhadap organisasi. Pegawai juga merasa adanya desakan waktu dalam menyelesaikan pekerjaan sehingga pegawai merasa waktu yang harusnya dapat 
diberikan untuk berkumpul bersama keluarga harus terbagi untuk pekerjaan yang harus diselesaikan tepat waktu, selain itu faktor lain yang menyebabkan komitmen organisasional pegawai bank BRI Unit Diponogoro rendah adalah adanya tekanan yang di berikan oleh atasan untuk memenuhi target yang telah ditetapkan (seperti mencari nasabah yang mengajukan kredit). Hal tersebut mengakibatkan komitmen organisasional yang dimiliki pegawai di BRI Unit Diponogoro Denpasar rendah dan akan berdampak pada menurunnya efektivitas di BRI Unit Diponogoro Denpasar. Kondisi ini menunjukkan perlu adanya perhatian khusus dari pimpinan atau atasan BRI Unit Diponogoro Denpasar kepada pegawai agar komitmen organisasional pegawai bisa di tingkatkan guna mendukung tujuan organisasi.

Teori yang digunakan dalam penelitian ini adalah Two Factor Theory, yang menganjurkan bahwa kepuasan dan ketidakpuasan merupakan bagian dari kelompok variabel yang berbeda yaitu motivators dan hygiene factors. Ketidakpuasan dihubungkan dengan kondisi disekitar pekerjaan (seperti kondisi kerja, upah, keamanan, kualitas pengawasan dan hubungan dengan orang lain) dan bukan dengan pekerjaan itu sendiri. Karena faktor mencegah 16 reaksi negatif dinamakan sebagai hygiene atau maintainance factors. Sebaliknya kepuasan ditarik dari faktor yang terkait dengan pekerjaan itu sendiri atau hasil langsung daripadanya seperti sifat pekerjaan, prestasi dalam pekerjaan, peluang promosi dan kesempatan untuk pengembangan diri dan pengakuan. Karena faktor ini berkaitan dengan tingkat kepuasan kerja tinggi dinamakan motivators Herzberg (Mohammadi et al., 2015)

Teori kedua adalah Value Theory. Menurut teori ini kepuasan kerja terjadi pada tingkatan dimana hasil pekerjaan diterima individu seperti diharapkan. Semakin banyak orang menerima hasil, akan semakin puas dan sebaliknya. Kunci menuju kepuasan pada teori ini adalah perbedaan antara aspek pekerjaan yang dimiliki dengan yang diinginkan seseorang. Semakin besar perbedaan, semakin rendah kepuasan orang (Andrade et al., 2016).

Hasil penelitian dari Divara (2016) mengatakan bahwa work family conflict berpengaruh negatif signifikan terhadap komitmen organisasional. Kusumandari et al. (2017) mengatakan bahwa work family conflict berpengaruh negatif dan signifikan terhadap komitmen organisasional. Penelitaian Utama et al. (2015) mengatakan bahwa work-family conflict berpengaruh negatif dan signifikan terhadap komitmen organisasional. Penelitian Malik (2015) menyatakan work family conflict berpengaruh negatif dan signifikan terhadap komitmen organisasional. Penelitian Hidayati et al. (2019) menyatakan bahwa work-family conflict berpengaruh negatif dan signifikan terhadap komitmen organisasional. Semakin rendah konflik makan semakin tinggi komitmen terhadap perusahaan. Berdasarkan landasan teori pada penelitian sebelumnya dapat dikemukakan hipotesis sebagai berikut.

$\mathrm{H}_{1}$ : Work family conflict berpengaruh negatif signifikan terhadap komitmen organisasional.

Hasil penelitian dari Kusumandari et al. (2017) menyatakan bahwa Stres kerja berpengaruh negatif dan signifikan terhadap komitmen organisasional. Stres kerja berpengaruh negatif pada komitmen organisasi karena semakin tinggi stres mengakibatkan semakin menurunnya komitmen organisasi (Iresa et al., 2015). 
Sedangkan stres kerja berpengaruh positif dan tidak signifikan terhadap kinerja pegawai, sehingga stres kerja terbukti tidak memberikan pengaruh yang buruk dan signifikan terhadap kinerja pegawai (Gharib et al., 2016). Dalam penelitian Divara (2016) menyatakan bahwa Stres kerja berpengaruh negatif signifikan terhadap komitmen organisasional. stres kerja menyebabkan efek negatif pada komitmen organisasi (Masihabadi et al. , 2015). Bhatti et al. (2016) juga menyatakan bahwa Stres kerja berpengaruh negatif signifikan terhadap komitmen organisasional. Komitmen organisasional akan tercipta apabila seorang dapat mengatasi tekanan atau stres dalam bekerja. Semakin tinggi tingkan stres kerja makan semakin rendah komitmen terhadap perusahaan yang dimana berdampak pada kepuasan kerja pegawai. Berdasarkan landasan teori pada penelitian sebelumnya dapat dikemukakan hipotesis sebagai berikut.

$\mathrm{H}_{2}$ : Stres kerja berpengaruh negatif signifikan terhadap komitmen organisasional.

Hasil peneltian dari Ariawan \& Sariyathi (2018) bahwa kepuasan kerja berpengaruh positif dan signifikan terhadap komitmen organisasi pegawai. penelitan tersebut juga di dukung oleh penelitaian Utama et al. (2015) bahwa kepuasan kerja berpengaruh positif dan signifikan terhadap komitmen organisasional. Hasil penelitian Ida et al. (2016) bahwa kepuasan kerja secara silmultan berpengaruh positif terhadap komitmen organisasional. Penelitian Mirah \& Netra (2018) juga menyatakan kepuasan kerja berpengaruh positif terhadap komitmen organisasional. Eliyana \& Ma'arif (2019) menunjukkan kepuasan kerja berpengaruh positif dan signifikan terhadap komitmen organisasi. Hal ini menunjukkan bahwa semakin tinggi kepuasan kerja maka akan semakin tinggi pula komitmen kerja pegawai. semakin tinggi kepuasan kerja yang dirasakan oleh pegawai, maka semakin termotivasi pula pegawai dalam peningkatan komitmen organisasinya dan sebaliknya, semakin rendah kepuasan kerja yang yang dirasakan oleh pegawai, maka semakin pegawai tidak termotivasi untuk meningkatkan komitmen organisasinya

$\mathrm{H}_{3}$ : Kepuasan kerja berpengaruh positif signifikan terhadap komitmen organisasional

\section{METODE PENELITIAN}

Penelitian ini merupakan penelitian kausal (causal research), yaitu mengidentifikasikan hubungan sebab-akibat antara variabel-variabel pembentuk model dengan menggunakan pendekatan kuantitatif yang bersifat asosiatif. Metode ini dipilih untuk mengetahui hubungan antara variabel work family conflict (X1), stres kerja (X2) dan kepuasan kerja (X3) terhadap komitmen organisasional (Y).Penelitian ini dilakukan pada Bank Bri Unit Diponogoro Denpasar. Yang berlokasi di J1. Nusa Kambangan No.9, Kota Denpasar Bali. Lokasi ini dipilih karena ditemukan masalah-masalah yang terkait dengan work family conflict, stres kerja dan kepuasan kerja yang berpengaruh terhadap komitmen organisasional pegawai. Selain itu pemilihan lokasi ini juga berdasarkan atas tersedianya data yang memadai dan dapat diolah oleh peneliti. Obyek dalam penelitian ini adalah pengaruh work family conflik, stres kerja dan kepuasan kerja terhadap komitmen 
organisasional pada seluruh pegawai di Bank Bri Unit Diponogoro Denpasar. Variabel bebas adalah work family conflict (X1), stres kerja (X2), dan kepuasan kerja (X3) dan variabel terikat adalah Komitmen Organisasional (Y).

Data kualitatif dalam penelitian berupa pendapat dari responden yang meliputi variabel bebas dan terikat. Data primer yang dikumpulkan dari penelitian ini adalah dengan melakukan wawancara dan kuisioner mengenai komitmen organisasi, work family conflict, stres kerja dan kepuasan kerja yang disebarkan kepada responden pegawai BRI Unit Diponogoro Denpasar. Sumber sekunder adalah data yang sudah dalam bentuk jadi atau dapat di katakana data yang sudah tersedia di BRI Unit Diponogoro Denpasar. Populasi dalam penelitian ini adalah seluruh pegawai di Bank Bri Unit Diponogoro Denpasar yang berjumlah 46 orang pegawai dan tidak termasuk 1 kepala unit. Teknik pengambilan sampel dalam penelitian ini menggunakan teknik sampling jenuh. Metode pengumpulan data dalam penelitian ini adalah Wawancara dan kuesioner.

\section{HASIL DAN PEMBAHASAN}

Data karakteristik responden adalah data responden yang dikumpulkan untuk mengetahui profil responden penelitian. Berdasarkan hasil penelitian yang dilakukan terhadap pegawai Bank BRI Unit Diponogoro Denpasar dapat diketahui karakteristik respondennya meliputi jenis kelamin, usia dan pendidikan terakhir yang dijelaskan pada Tabel 2.

Tabel 2.

Kaakteristik Responden Bank BRI Unit Diponogoro Denpasar

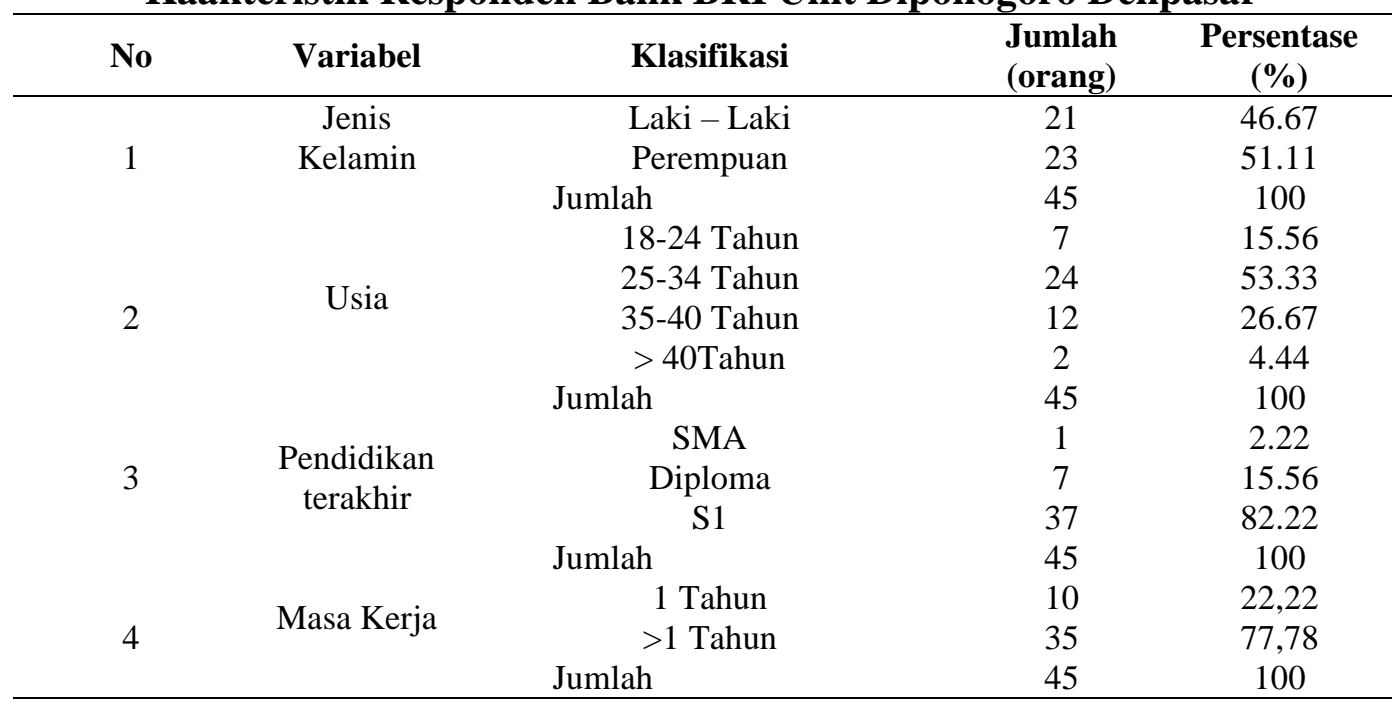

Sumber : Data diolah, 2019

Tabel 2. menunjukkan jumlah pegawai Bank BRI Unit Diponogoro Denpasar yang di jadikan sampel sebanyak 45 orang. Jika dilihat dari jenis kelamin, pegawai laki-laki sebanyak 21 dan pegawai perempuan mendominasi dalam penelitian ini sebanyak 23 dengan persentase sebesar 51,11 persen. Jika di lihat dari usia, yang memiliki usia 25-34 tahun mendominasi dengan presentase sebesar 53,33 persen, 
hal ini berarti Pegawai yang diperlukan perusahaan termasuk dalam kelompok usia produktif, karena dianggap sudah memiliki pengalaman yang cukup sehingga mampu bekerja dengan baik. Jika di lihat dari tingkat pendidikan yang memiliki tingkat pendiddikan terakhir S1 yang mendominasi dengan persentase sebesar 82,22 persen. Jika dilihat dari masa kerja pegawai yang menjadi responden dengan msa kerja satu tahun dengan presentase 22,22 persen dan lebih dari satu tahun dengan presentase 77,78 persen.

Tabel 3.

Hasil Uji Reliabilitas

\begin{tabular}{lc}
\hline \multicolumn{1}{c}{ Variabel } & Cronbach's Alpha \\
\hline Work Family Conflict (X1) & 0,866 \\
Stres kerja (X2) & 0,983 \\
Kepuasan kerja (X3) & 0,965 \\
Komitmen Organisasional Pegawai (Y) & 0,986 \\
\hline Sumber : Data diolah, 2019 &
\end{tabular}

Tabel 3. menunjukkan masing-masing nilai Cronbach's Alpha pada tiap instrumen tersebut lebih besar dari 0,6 (Cronbach's Alpha >0,6). Hal tersebut menunjukkan bahwa semua instrumen reliabel sehingga dapat digunakan untuk melakukan penelitian.

Tabel 4.

Hasil Uji Validitas

\begin{tabular}{|c|c|c|c|}
\hline No & Variabel & Item Pernyataan & Korelasi Item Total \\
\hline \multirow{3}{*}{1} & \multirow{3}{*}{ Work Family Conflict } & $\mathrm{X} 1.1$ & 0,832 \\
\hline & & $\mathrm{X} 1.2$ & 0,914 \\
\hline & & $\mathrm{X} 1.3$ & 0,919 \\
\hline \multirow{5}{*}{2} & \multirow{5}{*}{ Stres kerja } & $\mathrm{X} 2.1$ & 0,969 \\
\hline & & $\mathrm{X} 2.2$ & 0,977 \\
\hline & & $\mathrm{X} 2.3$ & 0,972 \\
\hline & & $\mathrm{X} 2.4$ & 0,975 \\
\hline & & $X 2.5$ & 0,969 \\
\hline \multirow{4}{*}{3} & \multirow{4}{*}{ Kepuasan kerja } & $\mathrm{X} 3.1$ & 0,868 \\
\hline & & X3.2 & 0,966 \\
\hline & & X3.3 & 0,940 \\
\hline & & X3.4 & 0,956 \\
\hline \multirow{10}{*}{4} & \multirow{10}{*}{ Komitmen Organisasional pegawai } & $\mathrm{X} 3.5$ & 0,960 \\
\hline & & Y1.1 & 0,963 \\
\hline & & Y1.2 & 0,962 \\
\hline & & Y1.3 & 0,958 \\
\hline & & Y1.4 & 0,852 \\
\hline & & Y1.5 & 0,958 \\
\hline & & Y1.6 & 0,971 \\
\hline & & Y1.7 & 0,958 \\
\hline & & Y1.8 & 0,965 \\
\hline & & Y1.9 & 0,963 \\
\hline
\end{tabular}

Sumber : Data diolah, 2019 
Tabel 4. menunjukkan bahwa seluruh koefisien korelasi dari indikator variabel yang diuji nilainya lebih besar dari $0,30(\mathrm{r}>0,3)$. Hasil tersebut menunjukkan bahwa seluruh indikator yang terdapat pada penelitian ini terbukti valid.

Variabel Komitmen Organisasional pegawai pada penelitian ini merupakan variabel terikat. Variabel Komitmen Organisasional pegawai yang disimbolkan dengan $\mathrm{Y}$ serta diukur dengan menggunakan 9 pernyataan yang ditanggapi menggunakan 5 poin Skala Likert. Data pada Tabel 5 menunjukkan bahwa pernyataan-pernyataan mengenai penilaian responden terhadap variabel komitmen organisasional memperoleh rata-rata 3,29. Data tersebut menunjukkan bahwa secara umum responden setuju terhadap pernyataan-pernyataan dari indikator komitmen organisasional sehingga dapat dikatakan bahwa komitmen organisasional yang dimiliki pegawai Bank BRI Unit Diponogoro Denpasar dikatagorikan cukup tinggi.

Tabel 5.

Deskripsi Jawaban Responden terhadap Komitmen Organisasional pegawai

\begin{tabular}{|c|c|c|c|c|c|c|c|c|c|}
\hline \multirow{3}{*}{ No } & \multirow{3}{*}{ Pernyataan } & \multirow{2}{*}{\multicolumn{5}{|c|}{$\begin{array}{c}\text { Proporsi Jawaban } \\
\text { Responden } \\
\text { (orang) }\end{array}$}} & \multirow{3}{*}{ Jumlah } & \multirow{3}{*}{$\begin{array}{l}\text { Rata- } \\
\text { Rata }\end{array}$} & \multirow{3}{*}{ Kriteria } \\
\hline & & & & & & & & & \\
\hline & & 1 & 2 & 3 & 4 & 5 & & & \\
\hline 1 & $\begin{array}{l}\text { Saya beruntung berada di } \\
\text { organisasi. }\end{array}$ & 2 & 10 & 6 & 25 & 2 & 150 & 3.33 & $\begin{array}{l}\text { Cukup } \\
\text { Tinggi }\end{array}$ \\
\hline 2 & $\begin{array}{l}\text { Organisasi memiliki makna } \\
\text { mendalam bagi saya. }\end{array}$ & 6 & 7 & 8 & 19 & 5 & 145 & 3.22 & $\begin{array}{l}\text { Cukup } \\
\text { Tinggi }\end{array}$ \\
\hline 3 & $\begin{array}{l}\text { Saya bangga terhadap } \\
\text { organisasi tempat saya } \\
\text { bekerja. }\end{array}$ & 6 & 7 & 8 & 19 & 5 & 145 & 3.22 & $\begin{array}{l}\text { Cukup } \\
\text { Tinggi }\end{array}$ \\
\hline 4 & $\begin{array}{l}\text { Saya merasa rugi apabila } \\
\text { keluar dari organisasi } \\
\text { tempat saya bekerja. } \\
\text { Saya menganggap bekerja }\end{array}$ & 0 & 12 & 14 & 12 & 7 & 149 & 3.31 & $\begin{array}{l}\text { Cukup } \\
\text { Tinggi }\end{array}$ \\
\hline 5 & $\begin{array}{lr}\text { pada organisasi } & \text { ini } \\
\text { merupakan } & \text { suatu } \\
\text { kebutuhan. } & \end{array}$ & 2 & 10 & 9 & 21 & 3 & 148 & 3.29 & $\begin{array}{l}\text { Cukup } \\
\text { Tinggi }\end{array}$ \\
\hline 6 & $\begin{array}{l}\text { Saya merasa bekerja pada } \\
\text { organisasi ini merupakan } \\
\text { kesempatan yang terbaik. }\end{array}$ & 6 & 7 & 10 & 16 & 6 & 144 & 3.20 & $\begin{array}{l}\text { Cukup } \\
\text { Tinggi }\end{array}$ \\
\hline 7 & $\begin{array}{l}\text { Saya bersedia dilibatkan } \\
\text { dalam kegiatan kerja demi } \\
\text { kepentingan organisasi. } \\
\text { Saya berkeinginan untuk }\end{array}$ & 5 & 7 & 11 & 16 & 6 & 146 & 3.24 & $\begin{array}{l}\text { Cukup } \\
\text { Tinggi }\end{array}$ \\
\hline 8 & $\begin{array}{l}\text { menghabisi sisa karir pada } \\
\text { organisasi tempat saya } \\
\text { bekerja. }\end{array}$ & 2 & 10 & 5 & 23 & 5 & 154 & 3.42 & Tinggi \\
\hline 9 & $\begin{array}{lr}\text { Saya tidak akan } \\
\text { meninggalkan } & \text { organisasi } \\
\text { karena masih } & \text { memiliki } \\
\text { kewajiban. } & \end{array}$ & 2 & 11 & 4 & 26 & 2 & 150 & 3.33 & $\begin{array}{l}\text { Cukup } \\
\text { Tinggi }\end{array}$ \\
\hline \multicolumn{8}{|c|}{ Rata-rata } & 3,29 & $\begin{array}{l}\text { Cukup } \\
\text { Tinggi }\end{array}$ \\
\hline
\end{tabular}

Sumber: Data diolah, 2019 
Variabel Komitmen Organisasional pegawai yang memiliki rata-rata terendah adalah pernyataan "Saya merasa bekerja pada organisasi ini merupakan kesempatan yang terbaik.", diperoleh nilai rata-rata sebesar 3,20 yang masuk kriteria cukup baik, tetapi memiliki nilai rata-rata yang rendah dibandingkan dengan pernyataan yang lainnya ini berarti secara umum responden merasa bekerja pada organisasi ini belum merupakan kesempatan yang terbaik. Variabel Komitmen Organisasional pegawai yang memiliki rata-rata tertinggi adalah pernyataan "Saya berkeinginan untuk menghabisi sisa karir pada organisasi tempat saya bekerja.", diperoleh nilai rata-rata sebesar 3,42 yang masuk kriteria baik, ini berarti secara umum responden berkeinginan untuk menghabisi sisa karir pada organisasi tempat saya bekerja.

Variabel Work Family Conflict pada penelitian ini merupakan variabel bebas. Variabel Work Family Conflict yang disimbolkan dengan $\mathrm{X}_{1}$ serta diukur dengan menggunakan 3 pernyataan yang ditanggapi menggunakan 5 poin Skala Likert. Data pada Tabel 6 menunjukkan bahwa pernyataan-pernyataan mengenai penilaian responden terhadap variabel work family conflict memperoleh rata-rata 2,79. Data tersebut menunjukkan bahwa secara umum responden kurang setuju terhadap pernyataan-pernyataan dari indikator work family conflic sehingga dapat dikatakan bahwa work family conflict yang dimiliki pegawai Bank BRI Unit Diponogoro Denpasar dikatagorikan cukup tinggi.

Tabel 6.

Deskripsi Jawaban Responden terhadap Work Family Conflict

\begin{tabular}{|c|c|c|c|c|c|c|c|c|c|}
\hline \multirow[t]{2}{*}{ No } & \multirow[t]{2}{*}{ Pernyataan } & \multicolumn{5}{|c|}{$\begin{array}{c}\text { Proporsi Jawaban } \\
\text { Responden } \\
\text { (orang) }\end{array}$} & \multirow[t]{2}{*}{ Jumlah } & \multirow[t]{2}{*}{$\begin{array}{l}\text { Rata- } \\
\text { Rata }\end{array}$} & \multirow[t]{2}{*}{ Kriteria } \\
\hline & & 1 & 2 & 3 & 4 & 5 & & & \\
\hline 1 & $\begin{array}{llr}\text { Saya } & \text { merasa } & \text { kesulitan } \\
\text { untuk } & \text { mengatur } & \text { waktu } \\
\text { antara } & \text { pekerjaan } & \text { dengan } \\
\text { keluarga } & & \end{array}$ & 6 & 17 & 9 & 8 & 5 & 124 & 2.76 & $\begin{array}{l}\text { Cukup } \\
\text { Tinggi }\end{array}$ \\
\hline 2 & $\begin{array}{l}\text { Saya merasa beban kerja } \\
\text { yang di berikan organisasi } \\
\text { menggangu waktu } \\
\text { berkumpul dengan keluarga } \\
\text { Pekeriaan kantor sering }\end{array}$ & 2 & 21 & 6 & 13 & 3 & 129 & 2.87 & $\begin{array}{l}\text { Cukup } \\
\text { Tinggi }\end{array}$ \\
\hline 3 & $\begin{array}{l}\text { saya kerjakan di rumah } \\
\text { sehingga menggangu waktu } \\
\text { senggang bersama keluarga }\end{array}$ & 8 & 13 & 10 & 11 & 3 & 123 & 2.73 & $\begin{array}{l}\text { Cukup } \\
\text { Tinggi }\end{array}$ \\
\hline \multicolumn{7}{|c|}{ Rata-rata } & & 2,79 & $\begin{array}{l}\text { Cukup } \\
\text { Tinggi }\end{array}$ \\
\hline
\end{tabular}

Variabel Work Family Conflict yang memiliki rata-rata terendah adalah pernyataan "Pekerjaan kantor sering saya kerjakan di rumah sehingga menggangu waktu senggang bersama keluarga", diperoleh nilai rata-rata sebesar 2,73 yang masuk kriteria cukup, tetapi memiliki nilai rata-rata yang rendah dibandingkan dengan pernyataan yang lainnya ini berarti secara umum Pekerjaan kantor mereka 
tidak kerjakan di rumah sehingga tidak menggangu waktu senggang bersama keluarga. Variabel Work Family Conflict yang memiliki rata-rata tertinggi adalah pernyataan "Saya merasa beban kerja yang di berikan organisasi menggangu waktu berkumpul dengan keluarga", diperoleh nilai rata-rata sebesar 2,87 yang masuk kriteria cukup baik, ini berarti secara umum responden menganggap merasa beban kerja yang di berikan organisasi menggangu waktu berkumpul dengan keluarga.

Variabel Stres kerja pada penelitian ini merupakan variabel bebas. Variabel Stres kerja yang disimbolkan dengan $\mathrm{X}_{2}$ serta diukur dengan menggunakan 5 pernyataan yang ditanggapi menggunakan 5 poin Skala Likert. Data pada Tabel 7 menunjukkan bahwa pernyataan-pernyataan mengenai penilaian responden terhadap variabel stres kerja memperoleh rata-rata 2,75. Data tersebut menunjukkan bahwa secara umum responden kurang setuju terhadap pernyataanpernyataan dari indikator stres kerja sehingga dapat dikatakan bahwa stres kerja yang dimiliki pegawai Bank BRI Unit Diponogoro Denpasar dikatagorikan cukup tinggi, dimana jika stres yang dimiliki pegawai tinggi akan menurunkan komitmen pegawai terhadap perusahaan.

Tabel 7.

Deskripsi Jawaban Responden terhadap Stres kerja

\begin{tabular}{|c|c|c|c|c|c|c|c|c|c|}
\hline \multirow{3}{*}{ No } & \multirow{3}{*}{ Pernyataan } & \multirow{2}{*}{\multicolumn{5}{|c|}{$\begin{array}{c}\text { Proporsi Jawaban } \\
\text { Responden } \\
\text { (orang) }\end{array}$}} & \multirow{3}{*}{ Jumlah } & \multirow{3}{*}{$\begin{array}{l}\text { Rata- } \\
\text { Rata }\end{array}$} & \multirow{3}{*}{ Kriteria } \\
\hline & & & & & & & & & \\
\hline & & 1 & 2 & 3 & 4 & 5 & & & \\
\hline 1 & $\begin{array}{l}\text { Saya memiliki keinginan } \\
\text { keluar dari pekerjaan } \\
\text { karena beban kerja cukup } \\
\text { berat }\end{array}$ & 4 & 22 & 5 & 10 & 4 & 123 & 2.73 & $\begin{array}{l}\text { Cukup } \\
\text { Tinggi }\end{array}$ \\
\hline 2 & $\begin{array}{l}\text { Saya merasa kinerja tidak } \\
\text { optimal karena } \\
\text { mengalami tekanan yang } \\
\text { berat dalam bekerja }\end{array}$ & 6 & 19 & 4 & 10 & 6 & 126 & 2.80 & $\begin{array}{l}\text { Cukup } \\
\text { Tinggi }\end{array}$ \\
\hline 3 & $\begin{array}{l}\text { Saya merasa stres kerja } \\
\text { membuat kinerja menurun } \\
\text { Saya sering meninggalkan }\end{array}$ & 6 & 17 & 7 & 13 & 2 & 123 & 2.73 & $\begin{array}{l}\text { Cukup } \\
\text { Tinggi }\end{array}$ \\
\hline 4 & $\begin{array}{l}\text { pekerjaan tanpa ijin } \\
\text { karena kondisi kerja yan } \mathrm{g} \\
\text { kurang nyaman }\end{array}$ & 4 & 22 & 5 & 12 & 2 & 121 & 2.69 & $\begin{array}{l}\text { Cukup } \\
\text { Tinggi }\end{array}$ \\
\hline 5 & $\begin{array}{l}\text { Saya merasa stres kerja } \\
\text { yang dialami cenderung } \\
\text { membuat malas bekerja } \\
\text { sehingga sering absen }\end{array}$ & 4 & 21 & 4 & 13 & 3 & 125 & 2.78 & $\begin{array}{l}\text { Cukup } \\
\text { Tinggi }\end{array}$ \\
\hline \multicolumn{8}{|c|}{ Rata-rata } & 2,75 & $\begin{array}{l}\text { Cukup } \\
\text { Tinggi }\end{array}$ \\
\hline
\end{tabular}

Variabel Stres kerja yang memiliki rata-rata terendah adalah pernyataan "Saya sering meninggalkan pekerjaan tanpa ijin karena kondisi kerja yan g kurang nyaman", diperoleh nilai rata-rata sebesar 2,69 yang masuk kriteria cukup, tetapi memiliki nilai rata-rata yang rendah dibandingkan dengan pernyataan yang lainnya ini berarti secara umum responden tidak meninggalkan pekerjaan tanpa 
ijin karena kondisi kerja yang kurang nyaman. Variabel Stres kerja yang memiliki rata-rata tertinggi adalah pernyataan "Saya merasa kinerja tidak optimal karena mengalami tekanan yang berat dalam bekerja", diperoleh nilai rata-rata sebesar 2,80 yang masuk kriteria cukup baik, ini berarti secara umum responden merasa kinerja tidak optimal karena mengalami tekanan yang berat dalam bekerja.

Variabel kepuasan kerja pada penelitian ini merupakan variabel bebas. Variabel kepuasan kerja yang disimbolkan dengan $\mathrm{X}_{3}$ serta diukur dengan menggunakan 5 pernyataan yang ditanggapi menggunakan 5 poin Skala Likert. Data pada Tabel 8 ditunjukkan bahwa pernyataan-pernyataan menyenai penilaian responden terhadap variabel kepuasan kerja memperoleh rata-rata 3,48. Data tersebut menunjukkan bahwa secara umum responden setuju terhadap pernyataanpernyataan dari indikator kepuasan kerja sehingga dapat dikatakan bahwa kepuasan kerja yang dimiliki pegawai Bank BRI Unit Diponogoro Denpasar dikatagorikan cukup baik.

Variabel kepuasan kerja yang memiliki rata-rata terendah adalah pernyataan "Saya merasa puas dengan pekerjaan yang saya lakukan", diperoleh nilai rata-rata sebesar 3,42 yang masuk kriteria baik, tetapi memiliki nilai ratarata yang rendah dibandingkan dengan pernyataan yang lainnya ini berarti secara umum responden belum merasa puas dengan pekerjaan yang mereka lakukan. Variabel kepuasan kerja yang memiliki rata-rata tertinggi adalah pernyataan "Saya merasa senang bekerja dengan rekan kerja saya di dalam perusahaan", diperoleh nilai rata-rata sebesar 3,62 yang masuk kriteria baik, ini berarti secara umum responden merasa senang bekerja dengan rekan kerja mereka di dalam perusahaan.

\section{Tabel 8.}

Deskripsi Jawaban Responden terhadap kepuasan kerja

\begin{tabular}{|c|c|c|c|c|c|c|c|c|c|}
\hline \multirow[t]{2}{*}{ No } & \multirow[t]{2}{*}{ Pernyataan } & \multicolumn{5}{|c|}{$\begin{array}{c}\text { Proporsi Jawaban } \\
\text { Responden } \\
\end{array}$} & \multirow[t]{2}{*}{ Jumlah } & \multirow{2}{*}{$\begin{array}{l}\text { Rata- } \\
\text { Rata }\end{array}$} & \multirow[t]{2}{*}{ Kriteria } \\
\hline & & 1 & 2 & 3 & 4 & 5 & & & \\
\hline 1 & $\begin{array}{l}\text { Saya merasa puas dengan } \\
\text { pekerjaan yang saya } \\
\text { lakukan }\end{array}$ & 0 & 13 & 9 & 14 & 9 & 154 & 3.42 & Baik \\
\hline 2 & $\begin{array}{l}\text { Gaji yang saya terima saat } \\
\text { ini sudah sesuai dengan } \\
\text { beban kerja saya }\end{array}$ & 1 & 10 & 6 & 24 & 4 & 155 & 3.44 & Baik \\
\hline 3 & $\begin{array}{l}\text { Saya menerima } \\
\text { kesempatan promosi } \\
\text { ketika saya melakukan } \\
\text { pekerjaan dengan baik }\end{array}$ & 1 & 9 & 8 & 21 & 6 & 157 & 3.49 & Baik \\
\hline 4 & $\begin{array}{l}\text { Atasan saya selalu } \\
\text { memberikan pengarahan } \\
\text { yang negatif terhadap } \\
\text { pekerjaan saya }\end{array}$ & 2 & 9 & 6 & 23 & 5 & 155 & 3.44 & Baik \\
\hline 5 & $\begin{array}{l}\text { Saya merasa senang } \\
\text { bekerja dengan rekan } \\
\text { kerja saya di dalam } \\
\text { perusahaan }\end{array}$ & 1 & 9 & 8 & 15 & 12 & 163 & 3.62 & Baik \\
\hline \multicolumn{7}{|c|}{ Rata-rata } & & 3,48 & $\begin{array}{l}\text { Cukup } \\
\text { Baik }\end{array}$ \\
\hline
\end{tabular}

Sumber : Data diolah, 2019 
Tabel 9.

Rangkuman Hasil Analisis Regresi Linear Berganda

\begin{tabular}{|c|c|c|c|c|c|}
\hline \multirow{2}{*}{ Model } & \multicolumn{2}{|c|}{$\begin{array}{l}\text { Unstandardized } \\
\text { Coefficients }\end{array}$} & \multirow{2}{*}{$\begin{array}{c}\begin{array}{c}\text { Standardized } \\
\text { Coefficients }\end{array} \\
\text { Beta } \\
\end{array}$} & \multirow[t]{2}{*}{$\mathbf{t}$} & \multirow[t]{2}{*}{ Sig. } \\
\hline & B & Std. Error & & & \\
\hline (Constant) & 4.086 & 0.843 & & 4.847 & 0.000 \\
\hline Work Family Conflict & -0.326 & 0.107 & -0.319 & -3.062 & 0.004 \\
\hline Stres kerja & -0.354 & 0.122 & -0.372 & -2.901 & 0.006 \\
\hline Kepuasan kerja & 0.311 & 0.141 & 0.290 & 2.199 & 0.034 \\
\hline
\end{tabular}

Sumber: Data diolah, 2019

$\mathrm{X}_{1}=-$ 0,326 menunjukkan bahwa Work Family Conflict berpengaruh negatif terhadap Komitmen Organisasional pegawai Bank BRI Unit Diponogoro Denpasar, apabila Work Family Conflict meningkat maka Komitmen Organisasional pegawai akan mengalami penurunan. $\mathrm{X}_{2}=-0,354$, menunjukkan bahwa Stres kerja berpengaruh negatif terhadap Komitmen Organisasional pegawai Bank BRI Unit Diponogoro Denpasar, apabila Stres Kerja pegawai meningkat maka Komitmen Organisasional pegawai akan mengalami penurunan. $X_{3}=+0,311$, menunjukkan bahwa Kepuasan kerja berpengaruh positif terhadap Komitmen Organisasional pegawai Bank BRI Unit Diponogoro Denpasar, apabila Kepuasan Kerja pegawai meningkat maka Komitmen Organisasional pegawai akan mengalami peningkatan

Tabel 10.

Uji Normalitas (One-Sample Kolmogorov-Smirnov)

\begin{tabular}{lr}
\hline & \multicolumn{2}{c}{ Unstandardized } \\
Residual & \\
\hline N & 45 \\
Kolmogorov-Smirnov Z & 0,669 \\
Asymp. Sig. (2-tailed) & 0,763 \\
\hline
\end{tabular}

Sumber: Data diolah, 2019

Uji normalitas dengan menggunakan One-Sample Kolmogorov-Smirnov Test yang ditampilkan pada Tabel 10 tersebut menunjukkan bahwa besarnya nilai Kolmogorov-Smirnov adalah sebesar 0,763. Nilai Kolmogorov-Smirnov tersebut lebih besar dibandingkan dengan nilai Kolmogorov-Smirnov tabel sebesar 0,05 maka $\mathrm{H}_{\mathrm{o}}$ diterima yang mengindikasikan bahwa data yang digunakan pada penelitian ini terdistribusi normal, sehingga dapat disimpulkan bahwa model memenuhi asumsi normalitas.

Tabel 11.

Uji Multikolinieritas (Tolerance dan Variance Inflation Factor)

\begin{tabular}{lrr}
\hline \multicolumn{1}{c}{ Variabel } & \multicolumn{2}{c}{ Collinearity Statistics } \\
\cline { 2 - 3 } & Tolerance & VIF \\
\hline Work Family Conflict & 0.764 & 1.309 \\
Stres kerja & 0.504 & 1.985 \\
Kepuasan kerja & 0.475 & 2.104 \\
\hline Sumber : Data diolah, 2019 &
\end{tabular}


Tabel 11. menunjukkan bahwa tidak terdapat variabel bebas yang memiliki nilai tolerance kurang dari 0,10 dan juga tidak ada variabel bebas yang memiliki nilai VIF lebih dari 10. Maka dari pada itu model regresi bebas dari gejala multikoleniaritas

Tabel 12. menunjukkan bahwa masing-masing model memiliki nilai signifikansi lebih besar dari 5\%. Hal ini menunjukkan bahwa variabel bebas yang digunakan pada penelitian ini tidak berpengaruh secara signifikan terhadap variabel terikatnya yaitu absolute error, maka dari itu, penelitian ini bebas dari gejala heteroskedastisitas.

Tabel 12.

Uji Heteroskedastisitas (Uji Glesjer)

\begin{tabular}{|c|c|c|c|c|c|}
\hline \multirow{2}{*}{ Variabel } & \multicolumn{2}{|c|}{ Unstandardized Coefficients } & \multirow{2}{*}{$\begin{array}{c}\text { Standardized } \\
\text { Coefficients } \\
\text { Beta }\end{array}$} & \multirow[t]{2}{*}{$\mathbf{t}$} & \multirow[t]{2}{*}{ Sig. } \\
\hline & $\mathbf{B}$ & Std. Error & & & \\
\hline (Constant) & 0.872 & 0.569 & & 1.532 & 0.133 \\
\hline $\begin{array}{l}\text { Work Family } \\
\text { Conflict }\end{array}$ & -0.058 & 0.072 & -0.142 & -0.802 & 0.427 \\
\hline Stres kerja & -0.013 & 0.082 & -0.034 & -0.154 & 0.878 \\
\hline Kepuasan kerja & -0.064 & 0.095 & -0.151 & -0.675 & 0.503 \\
\hline
\end{tabular}

Sumber: Data diolah, 2019

Tabel 13.

Analisis Determinasi

\begin{tabular}{lrrrr}
\hline Model & R & R Square & Adjusted R Square & $\begin{array}{c}\text { Std. Error of the } \\
\text { Estimate }\end{array}$ \\
\hline 1 & $0.813^{\mathrm{a}}$ & 0.661 & 0.636 & 0.64766 \\
\hline
\end{tabular}

Sumber : Data diolah, 2019

Berdasarkan hasil tersebut diketahui bahwa nilai $\mathrm{R}^{2}=66,1$ persen, yang berarti bahwa sebesar 66,1 persen Komitmen Organisasional pegawai Bank BRI Unit Diponogoro Denpasar dipengaruhi oleh variabel Work Family Conflict (X1), Stres kerja (X2), Kepuasan kerja (X3) dan sisanya sebesar 33,9 persen dipengaruhi oleh variabel lain yang tidak diteliti pada penelitian ini.

Tabel 14.

Hasil Uji F

\begin{tabular}{llrrrrr}
\hline Model & & Sum of Squares & df & Mean Square & F & Sig. \\
\hline \multirow{2}{*}{1} & Regression & 33.463 & 3 & 11.154 & 26.591 & $0.000^{\mathrm{b}}$ \\
& Residual & 17.198 & 41 & 0.419 & & \\
& Total & 50.661 & 44 & & & \\
\hline
\end{tabular}

Sumber : Data diolah, 2019

Berdasarkan hasil analisis, diketahui nilai signifikansi $\mathrm{F}$ adalah $0,000<0,05$, maka $\mathrm{H}_{0}$ ditolak. Hal ini berarti bahwa variabel Work Family Conflict $\left(\mathrm{X}_{1}\right)$, variabel Stres kerja $\left(\mathrm{X}_{2}\right)$, variabel Kepuasan kerja $\left(\mathrm{X}_{3}\right)$, secara simultan berpengaruh signifikan terhadap Komitmen Organisasional pegawai (Y) Bank BRI 
Unit Diponogoro Denpasar, atau model yang digunakan dalam penelitian layak dan dapat dipergunakan untuk analisis berikutnya.

Tabel 15.

Hasil Uji t

\begin{tabular}{llr}
\hline Variabel & Unstandardized Coefficients Beta & Sig. \\
\hline Work Family Conflict & $-0,326$ & 0,004 \\
Stres kerja & $-0,354$ & 0,006 \\
Kepuasan kerja & 0,311 & 0,034 \\
\hline
\end{tabular}

Sumber : Data diolah, 2019

Berdasarkan hasil analisis di atas dapat dijelaskan bahwa tingkat signifikansi $0,004<0,05$, sehingga $\mathrm{H}_{0}$ ditolak dan $\mathrm{H}_{\mathrm{a}}$ diterima yang berarti bahwa variabel Work Family Conflict berpengaruh negatif signifikan terhadap Komitmen Organisasional pegawai. Koefisien regresi $\beta 1$ (variabel Work Family Conflict) sebesar -0,326, menunjukkan bahwa meningkatnya Work Family Conflict maka akan menurunkan Komitmen Organisasional pegawai Bank BRI Unit Diponogoro Denpasar. Tingkat signifikansi $0,006<0,05$, sehingga $\mathrm{H}_{0}$ ditolak dan $\mathrm{H}_{\mathrm{a}}$ diterima yang berarti bahwa variabel Stres kerja berpengaruh negatif signifikan terhadap Komitmen Organisasional pegawai. Koefisien regresi $\beta 2$ (variabel Stres kerja) sebesar -0,354, menunjukkan bahwa meningkatnya Stres kerja maka akan menurunkan Komitmen Organisasional pegawai Bank BRI Unit Diponogoro Denpasar. Tingkat signifikansi $0,034<0,05$, sehingga $\mathrm{H}_{0}$ ditolak dan $\mathrm{H}_{\mathrm{a}}$ diterima yang berarti bahwa variabel Kepuasan kerja berpengaruh positif signifikan terhadap Komitmen Organisasional pegawai. Koefisien regresi $\beta 3$ (variabel Kepuasan kerja) sebesar 0,311, menunjukkan bahwa meningkatnya Kepuasan kerja maka akan meningkatkan Komitmen Organisasional pegawai Bank BRI Unit Diponogoro Denpasar.

Nilai signifikan untuk variabel work family conflict sebesar 0,004 terhadap variabel komitmen organisasional. Berdasarkan nilai pengujian tersebut, dapat dilihat dengan statistik bahwa $\mathrm{H}_{0}$ ditolak dan $\mathrm{H}_{1}$ diterima untuk hipotesis pertama. Hal tersebut menyatakan penerimaan hipotesis yang bahwa terdapat pengaruh negatif dan signifikan antara Work Family Conflict terhadap Komitmen Organisasional pegawai Bank BRI Unit Diponogoro Denpasar. Koefisien variabel $\mathrm{X} 1$ adalah negatif 0,326 artinya Work Family Conflict berpengaruh negatif terhadap Komitmen Organisasional pegawai.

Hasil penelitian ini sesuai dengan penelitian yang dilakukan oleh Divara (2016) mengatakan bahwa work family conflict berpengaruh negatif signifikan terhadap komitmen organisasional. Kusumandari et al. (2017) mengatakan bahwa work family conflict berpengaruh negatif dan signifikan terhadap komitmen organisasional. Penelitaian Utama et al. (2015) mengatakan bahwa work-family conflict berpengaruh negatif dan signifikan terhadap komitmen organisasional.. Penelitian Hidayati et al. (2019) menyatakan bahwa work-family conflict berpengaruh negatif dan signifikan terhadap komitmen organisasional. Semakin rendah konflik makan semakin tinggi komitmen terhadap perusahaan.

Nilai signifikan untuk variabel stres kerja sebesar 0,006 terhadap variabel komitmen organisasional. Berdasarkan nilai pengujian tersebut, dapat dilihat 
dengan statistik bahwa $\mathrm{H}_{0}$ ditolak dan $\mathrm{H}_{1}$ diterima untuk hipotesis kedua. Hal tersebut menyatakan penerimaan hipotesis yang bahwa terdapat pengaruh negatif dan signifikan antara terhadap Komitmen Organisasional pegawai Bank BRI Unit Diponogoro Denpasar. Koefisien variabel X2 adalah negatif 0,354, artinya Stres kerja berpengaruh negatif terhadap Komitmen Organisasional pegawai.

Hasil penelitian ini sesuai dengan penelitian yang dilakukan oleh Kusumandari et al. (2017) menyatakan bahwa Stres kerja berpengaruh negatif dan signifikan terhadap komitmen organisasional. Stres kerja berpengaruh negatif pada komitmen organisasi karena semakin tinggi stres mengakibatkan semakin menurunnya komitmen organisasi (Iresa et al., 2015). Dalam penelitian Divara (2016) menyatakan bahwa Stres kerja berpengaruh negatif signifikan terhadap komitmen organisasional. stres kerja menyebabkan efek negatif pada komitmen organisasi. Bhatti et al. (2016) juga menyatakan bahwa Stres kerja berpengaruh negatif signifikan terhadap komitmen organisasional. Komitmen organisasional akan tercipta apabila seorang dapat mengatasi tekanan atau stres dalam bekerja. Semakin tinggi tingkan stres kerja makan semakin rendah komitmen terhadap perusahaan yang dimana berdampak pada kepuasan kerja pegawai.

Nilai signifikan untuk variabel kepuasan kerja sebesar 0,034 terhadap variabel komitmen organisasional. Berdasarkan nilai pengujian tersebut, dapat dilihat dengan statistik bahwa $\mathrm{H}_{0}$ ditolak dan $\mathrm{H}_{1}$ diterima untuk hipotesis ketiga. Hal tersebut menyatakan penerimaan hipotesis bahwa terdapat pengaruh positif dan signifikan antara kepuasan kerja terhadap komitmen organisasional pegawai Bank BRI Unit Diponogoro Denpasar. Koefisien variabel X3 adalah positif 0,311, artinya Kepuasan kerja berpengaruh positif terhadap Komitmen Organisasional pegawai.

Hasil penelitian ini sesuai dengan penelitian yang dilakukan oleh Ariawan \& Sariyathi (2018) bahwa kepuasan kerja berpengaruh positif dan signifikan terhadap komitmen organisasi pegawai. penelitan tersebut juga di dukung oleh penelitaian Utama et al. (2015) bahwa kepuasan kerja berpengaruh positif dan signifikan terhadap komitmen organisasional. Hasil penelitian Ida et al. (2016) bahwa kepuasan kerja secara silmultan berpengaruh positif terhadap komitmen organisasional. Penelitian Mirah \& Netra (2018) juga menyatakan kepuasan kerja berpengaruh positif terhadap komitmen organisasional. Eliyana \& Ma'arif (2019) menunjukkan kepuasan kerja berpengaruh positif dan signifikan terhadap komitmen organisasi. Hal ini menunjukkan bahwa semakin tinggi kepuasan kerja maka akan semakin tinggi pula komitmen kerja pegawai. Semakin tinggi kepuasan kerja yang dirasakan oleh pegawai, maka semakin termotivasi pula pegawai dalam peningkatan komitmen organisasinya dan sebaliknya, semakin rendah kepuasan kerja yang yang dirasakan oleh pegawai, maka semakin pegawai tidak termotivasi untuk meningkatkan komitmen organisasinya

Implkasi teoritis dari hasil penelitin ini memberikan bukti mengenai Work Family Conflict, Stres Kerja, Kepuasan Kerja dan Komitmen Organisasional pegawai. Secara teoritis penelitian ini juga memberikan pemahaman bahwa Work Family Conflict, Stres Kerja menurunkan Komitmen Organisasional pegawai dan Kepuasan Kerja secara nyata dapat meningkatkan Komitmen Organisasional pegawai. Jika Work Family Conflict dan Stres Kerja meningkat maka Komitmen Organisasional pegawai akan mengalami penurunan, Sedangkan jika kepuasan 
kerja meningkat maka Komitmen Organisasional pegawai akan mengalami peningkatan.

Penelitian ini dilakukan hanya sebatas pada ruang lingkup Bank BRI Unit Diponogoro Denpasar, sehingga hasil penelitian ini tidak dapat digunakan pada perusahaan lain. Faktor-faktor yang mempengaruhi komitmen organisasional pegawai Bank BRI Unit Diponogoro Denpasar dalam penelitian ini adalah work family conflict stres kerja dan kepuasan kerja, sedangkan masih banyak faktor lain yang dapat mempengaruhi.

\section{SIMPULAN}

Terdapat pengaruh negatif dan signifikan antara Work Family Conflict terhadap Komitmen Organisasional pegawai Bank BRI Unit Diponogoro Denpasar Hal ini berarti semakin tinggi Work Family Conflict, maka semakin rendah Komitmen Organisasional pegawai. Terdapat pengaruh negatif dan signifikan antara Stres kerja terhadap Komitmen Organisasional pegawai Bank BRI Unit Diponogoro Denpasar. Hal ini berarti semakin tinggi Stres kerja, maka semakin rendah Komitmen Organisasional pegawai. Terdapat pengaruh positif dan signifikan antara Kepuasan kerja terhadap Komitmen Organisasional pegawai Bank BRI Unit Diponogoro Denpasar. Hal ini berarti semakin tinggi Kepuasan kerja, maka semakin meningkatkan juga Komitmen Organisasional pegawai.

Perusahaan disarankan untuk tidak terlalu memberikan beban kerja yang tinggi agar pegawai dapat meluangkan waktunya bersama keluarga. Perusahaan disarankan untuk tidak terlalu memberi tekanan yang berat terhadap pegawai dan memberikan waktu untuk refreshing kepada pegawai agar pegawai merasa nyaman dalam bekerja. Perusahaan disarankan memberikan reward kepada pegawai yang telah bekerja dengan semangat agar mereka merasa puas bekerja di Bank BRI Unit Diponogoro Denpasar. Bagi penelitian selanjutnya diharapkan mampu menambah variabel-variabel lain yang dapat mempengaruhi komitmen organisasional seperti variabel lingkungan kerja, budaya organisasi, kompensasi dan lain-lain, serta mampu untuk memperluas ruang lingkup penelitian yang tidak hanya terbatas Bank BRI Unit Diponogoro Denpasar, atau dapat juga mengganti lokasi penelitian yang tidak hanya terfokus pada satu lokasi penelitian, sehingga memberikan suatu pandangan yang lebih dan mampu diimplementasikan secara umum.

\section{REFERENSI}

Andrade, T. de V. F. C., Vania, de F. B. E., \& Leticia, L. (2016). Organizational citizenship behaviors: a glimpse in the light of values and job satisfaction. Review of Business Management, 19(64), 236-262.

Ariawan, P. A. Y., \& Sriathi, A. A. A. (2018). Pengaruh Stres Kerja dan Kepuasan Kerja terhadap Komitmen Organisasional PBF. Banyumas Denpasar. EJurnal Manajemen Unud, 71(2), 964-992.

Arifin, H. M. (2015). The Influence of Competence, Motivation, and 
Organizational Culture to High School Teacher Job Satisfaction and Performance. International Education Studies, 8(1), 38-45.

Batur, O., \& Nart, S. (2015). The Relation between Work-Family Conflict, Job Stress, Organizational Commitment and Job Performance: A Study on Turkish Primary Teachers. European Journal of Research on Education, 2(1), 72-81.

Bhatti, M. H., Bhatti, M. H., Akram, M. U., Hashim, M., \& Akram, Z. (2016). Relationship between job stress and organizational commitment: An empirical study of banking sector. E3 Journal of Business Management and Economics, 7(1), 029-037. https://doi.org/10.18685/ejbme(7)1_ejbme-15-013

Divara, I. G. A. G. K. (2016). Pengaruh Work Family Conflict Terhadap Stres Kerja Dan Komitmen Organisasional Pegawai Kontrak Dinas Kebudayaan Provinsi Bali. E-Jurnal Manajemen Unud, 5(11), 6974-7001.

Eliyana, A., \& Ma'arif, S. (2019). Job satisfaction and organizational commitment effect in the transformational leadership towards employee performance. European Research on Management and Business Economics, 25(3), 144150.

Gharib, M. N., Jamil, S. A., Ahmad, M., \& Ghouse, S. (2016). The impact of job stress on job performance: A case study on academic staff at dhofar university. International Journal of Economic Research, 13(1), 21-33.

Harun, H., Rohani, S., Mumtaz, A., Memon., M. N., Rosli, B., \& Azrai, A. (2015). Job Satisfaction, Organizational Commitment and Stress among Offshore Oil and Gas Platform Employees. Asian Social Science, 10(11), 28-32.

Hidayati, N., Zarlis, M., \& Absah, Y. (2019). Effect of Work-Family Conflict on Commitment Organization Through Work Stress with Religiosityas A Moderating Variable in Health Workers of Latersia Binjai Hospital. IJJR Journal, 6(May), 167-186.

Ida, M. Y., Supartha, W. G., \& Sebudi, M. (2016). Pengaruh Pemberdayaan dan Kepuasan Kerja Terhadap Komitmen Organisasional Guru di SMK N 1 MAS UBUD. E-Jurnal Ekonomi Dan Bisnis Universitas Udayana, 5(12), 41774208.

Iresa, A. R., Hamidah, N. U., \& Arik, P. (2015). Pengaruh Konflik Kerja Dan Stres Kerja Terhadap Komitmen Organisasional Dan Kinerja Pegawai (Studi pada Pegawai PT. Telekomunikasi Indonesia, Tbk Witel Malang). Jurnal Administrasi Bisnis (JAB), 23(1), 1-10.

Jamadin, N., Samsiah, M., Syarkawi, Z., \& Fauziah, N. (2015). Work FamilyConflict and Stress: Evidence From Malaysia. Journal of Economics, Business and Management, 3(2), 309-312. 
Kusumandari, N. P. L., Sudibya, I. G. A., \& Ardana, I. K. (2017). Pengaruh Work Family Conflict Dan Stres Kerja Terhadap Komitmen Organisasional Sma N 1 Kuta Utara. E-Jurnal Manajemen Unud, 6(9), 4919-4996.

Malik, S. (2015). Role of Work Family Conflict on Organizational Commitment and Organizational Effectiveness. European Journal of Business and Management, 7(1), 222-230. Retrieved from http://iiste.org/Journals/index.php/EJBM/article/view/18896

Malik, S., Awan, A. G., \& Qurat-Ul-Ain. (2015). Role Of Work Family Conflict On Organizational Commitment And Organizational. IOSR Journal of Businees an Management, 1(1), 1-12.

Masihabadi, A., Rajaei, A., Shams Koloukhi, A., \& Parsian, H. (2015). Effects of stress on auditors organizational commitment, job satisfaction, and job performance. International Journal of Organizational Leadership, 4(3), 303314. https://doi.org/10.33844/ijol.2015.60353

Mirah, L. V. A. S., \& Netra, I. G. S. K. (2018). Peran Kepuasan Kerja Dalam Memediasi Pengaruh Kecerdasan Emosional Terhadap Komitmen Organisasional. E-Jurnal Manajemen Unud, 8(3), 1813-1843.

Mohammadi, M., Porkiani, M., \& Beheshtifar, M. (2015). The study of the relation between work-family conflict with organizational commitment among the staffs of Tejarat bank branches of Kerman. Applied Mathematics in Engineering, Management and Technology, 2(2), 88-99.

Moura, D., Oegambieze-Ramos, A., \& Goncal, G. (2015). Role Stress and Work Engagement as Antecedents of Job Satisfaction: Results From Portugal. Europe's Journal of Psychology, 10(2), 291-300.

Nurcahyani, N. M., \& Adnyani, I. G. A. D. (2016). Pengaruh Kompensasi dan Motivasi Terhadap Kinerja Pegawai Dengan Kepuasan Kerja Sebagai Variabel Intervening. E-Jurnal Manajemen Unud, 5(1), 500-532.

Sunarno, \& Liana, L. (2015). Pengaruh Komitmen Organisasional dan Budaya Organisasi terhadap Kinerja Guru Dimediasi Kepuasan Kerja (Studi Kasus pada Guru SMA Kesatrian dalam Yayasan Pendidikan Kesatrian). Multi Disiplin, 1(1), 1-16.

Utama, D. G., Satria, A., \& Sintaasih, D. K. (2015). Pengaruh Work - Family Conflict dan Kepuasan Kerja Terhadap Komitmen Organisasional dan Turnover Intention. E-Jurnal Manajemen Unud, 4(11), 3703-3737.

Wang, Y., Zeyuan, L., Yue, W., \& Fang, G. (2017). Psychological Contract and Turnover Intention: The Mediating Role of Organizational Commitment. 
E-Jurnal Manajemen, Vol. 9, No. 6, 2020 : 2374-2393

Journal of Human Resource and Sustainability Studies, 6(1), 21-35.

Yantha, P. I. (2015). Analisis Pengaruh Work Family Conflict Dan Role Stres Terhadap Komitmen Organisasional Pegawai The Clubs Villas Seminyak Bali. E-Jurnal Managemen Unud, 5(4), 2573-2605. 